Article

\title{
Improving Water Sustainability and Food Security through Increased Crop Water Productivity in Malawi
}

\author{
Luxon Nhamo ${ }^{1, *}$, Tafadzwanashe Mabhaudhi ${ }^{2}$ and Manuel Magombeyi ${ }^{1}$ \\ 1 International Water Management Institute (IWMI), 141 Cresswell St., Weavind Park, Silverton 0184, Pretoria, \\ South Africa; M.Magombeyi@cgiar.org \\ 2 School of Agricultural, Earth and Environmental Sciences, University of KwaZulu-Natal (UKZN), \\ Private Bag X01, Scottsville 3209, Pietermaritzburg, South Africa; Mabhaudhi@ukzn.ac.za \\ * Correspondence: 1.nhamo@cgiar.org; Tel.: +27-12-845-9100
}

Academic Editor: Ranka Junge

Received: 19 July 2016; Accepted: 14 September 2016; Published: 21 September 2016

\begin{abstract}
Agriculture accounts for most of the renewable freshwater resource withdrawals in Malawi, yet food insecurity and water scarcity remain as major challenges. Despite Malawi's vast water resources, climate change, coupled with increasing population and urbanisation are contributing to increasing water scarcity. Improving crop water productivity has been identified as a possible solution to water and food insecurity, by producing more food with less water, that is, to produce "more crop per drop". This study evaluated crop water productivity from 2000 to 2013 by assessing crop evapotranspiration, crop production and agricultural gross domestic product (Ag GDP) contribution for Malawi. Improvements in crop water productivity were evidenced through improved crop production and productivity. These improvements were supported by increased irrigated area, along with improved agronomic practices. Crop water productivity increased by 33\% overall from 2000 to 2013, resulting in an increase in maize production from 1.2 million metric tons to 3.6 million metric tons, translating to an average food surplus of 1.1 million metric tons. These developments have contributed to sustainable improved food and nutrition security in Malawi, which also avails more water for ecosystem functions and other competing economic sectors.
\end{abstract}

Keywords: agricultural gross domestic product (Ag GDP); crop evapotranspiration; food security; water management; water productivity; crop productivity; water scarcity

\section{Introduction}

Water scarcity and food insecurity are among the major challenges facing humankind today. The two cannot be studied separately as water is the key resource for food production, and crop production is the largest global consumer of freshwater resources [1-3]. With the ever growing world population, urbanisation and limited water resources, there is an increasing need worldwide for improved water resources management. Thus, producing more food per each drop of water is crucial to address both challenges of water scarcity and food insecurity [4,5]. Improving water use efficiency or enhancing crop water productivity is a critical response to increasing water scarcity, including maintaining sufficient water in rivers and lakes to sustain ecosystems and to meet the growing demands of cities and industries [6].

Water productivity (WP) is the ratio of the net benefits from agricultural systems (crop, forestry, fishery, livestock and mixed farming) to the amount of water consumed [7]. It reflects the ability to produce more food and income, while improving livelihoods and ecological benefits at less social and environmental cost per unit of water consumed. Therefore, WP can simply mean growing more food or gaining more agricultural benefits with less water $[7,8]$. There are two main types of WP, physical and economic. Physical WP is the ratio of the mass of agricultural output to the amount of water consumed, 
and economic WP is the monetary value derived per unit of water consumed $[3,4,9]$. There is also another dimension to WP which links agriculture to nutrition. This has been termed nutritional WP and describes the nutritional content per volume of water consumed [10]. Sustainable food production should also focus on dietary requirements and their relation to scarce water resources, a concept that has also been highlighted by the Stockholm International Water Institute (SIWI) and the International Water Management Institute (IWMI) [11] under the idea of "more nutrition per drop".

According to previous studies, there are considerable gains to be made regarding WP, although this does not apply to all areas $[7,12]$. Regions already exhibiting high physical WP have limited space for improvements. The areas with the highest potential gains in improved WP are those with very low yields and that rely on rainfed agricultural systems. This situation mirrors Malawi, a country in sub-Saharan Africa, whose economy is largely agro-based. Smallholder farmers, who cultivate most of the arable land in Malawi, depend on highly variable rainfall and this has been associated with low crop yields. This scenario is similar to that experienced by smallholder farmers across sub-Saharan Africa who depend on rainfed agriculture.

In Malawi, agriculture remains very important to the economy as it contributes more than one-third to the gross domestic product (GDP), over $90 \%$ of export earnings, employs almost half of those in paid employment, and supports at least $81 \%$ of the population [13]. As a result of being an agro-based economy, agriculture is therefore the largest consumer of water, with about $79 \%$ of the total water withdrawn annually used for agriculture. This creates pressure to reallocate water to other competing economic sectors and highlights the need for improved agricultural water management in Malawi. Water resources need to be managed properly in Malawi due to the recurrence of the El Niño-Southern Oscillation (ENSO)—induced droughts that are causing water scarcity. Improving WP in the agriculture sector has the benefit of releasing more water to other competing sectors [14], provided the water is used efficiently. Malawi, being a very small country with a total surface area of 118 million $\mathrm{km}^{2}$, has limited options to increase its agricultural area; therefore, increasing crop productivity on existing cropped area is an important pathway to improve food and water security for supporting economic development and improving the livelihoods of the rural majority. More productive use of water could mean better nutrition for families, more income and productive employment for the rural poor. Some reasons to improve crop WP include: (a) to meet the rising demand for food and nutrition from an increasing urbanised population, in light of water scarcity; (b) to respond to pressures to reallocate water from agriculture and make it available to other competing economic sectors; (c) to contribute to poverty reduction and economic growth $[5,7,15]$; and (d) to adapt to climate change and variability.

Not much has been done to assess crop WP at a national level in Malawi. Most studies have focussed on crop-water requirements for irrigation planning and scheduling for staple crops at a field level $[16,17]$. While such studies are beneficial for improving farm management practices, they are difficult to extrapolate to national level which is needed to inform policy. Therefore, the objective of this study was to assess crop WP and evaluate the incremental welfare (income, nutrition and livelihoods) per unit of water consumed in the agricultural sector as a result of the huge investment put into the sector by the government and other stakeholders over the years. The study evaluated the trend in crops produced per unit of water consumed over time. A comparison of crop water productivity between irrigated and rainfed agricultural systems was done to assess the yield gap in terms of water productivity. The study also assessed how improved crop water productivity was impacting food and nutritional security in Malawi. The aim was to manage water resources better and improve water sustainability and food security through the production of more crops with less water in an era of climate change and variability and increasing population and urbanisation. 


\section{Materials and Methods}

\subsection{Study Area}

Malawi, a Sub-Saharan country in southern Africa, is located between latitudes $9^{\circ} 22^{\prime} \mathrm{S}$ and $17^{\circ} 03^{\prime} \mathrm{S}$ and longitudes $33^{\circ} 40^{\prime} \mathrm{E}$ and $35^{\circ} 55^{\prime} \mathrm{E}$ with a surface area of $118,480 \mathrm{~km}^{2}$. Approximately $94,276 \mathrm{~km}^{2} \mathrm{of}^{\circ}$ this surface area is land and the rest is water, mainly Lake Malawi. It is bordered by Tanzania to the north and northeast, Mozambique to the south and southwest, and Zambia to the west. About $94 \%$ of the land area in Malawi is part of the Zambezi River Basin. The remaining 6\% falls within the small internal drainage basin of Lake Chilwa. Major crops grown in Malawi include maize, wheat, groundnuts, sorghum, millet, pulses, rice, root crops, vegetables, fruits and tobacco, among others. Maize is the staple crop.

There are four recognised main physiographic zones in Malawi, namely, The Highland, The Plateau, The Escarpment and The Rift Valley Floor. Its sub-tropical climate is relatively dry and strongly seasonal. The warm-wet season stretches from November to April, during which 95\% of the annual precipitation is received. Annual average rainfall varies from $725 \mathrm{~mm}$ to $2500 \mathrm{~mm}$ with Lilongwe having an average of $900 \mathrm{~mm}$, Blantyre $1127 \mathrm{~mm}$, Mzuzu $1289 \mathrm{~mm}$ and Zomba $1433 \mathrm{~mm}$. However, the rainfall pattern is generally erratic, which poses a significant threat to agricultural production and economic growth.

Malawi's population, currently estimated at more than 16 million [18], is spread across three regions, Northern, Central and Southern, and these regions are further divided into 28 districts. About $79 \%$ of the population lives in rural areas depending on agriculture. As a result, Malawi is still predominantly an agricultural-based society and agriculture dominates the land use classifications for the country. The landuse/cover map of Malawi is shown in Figure 1.

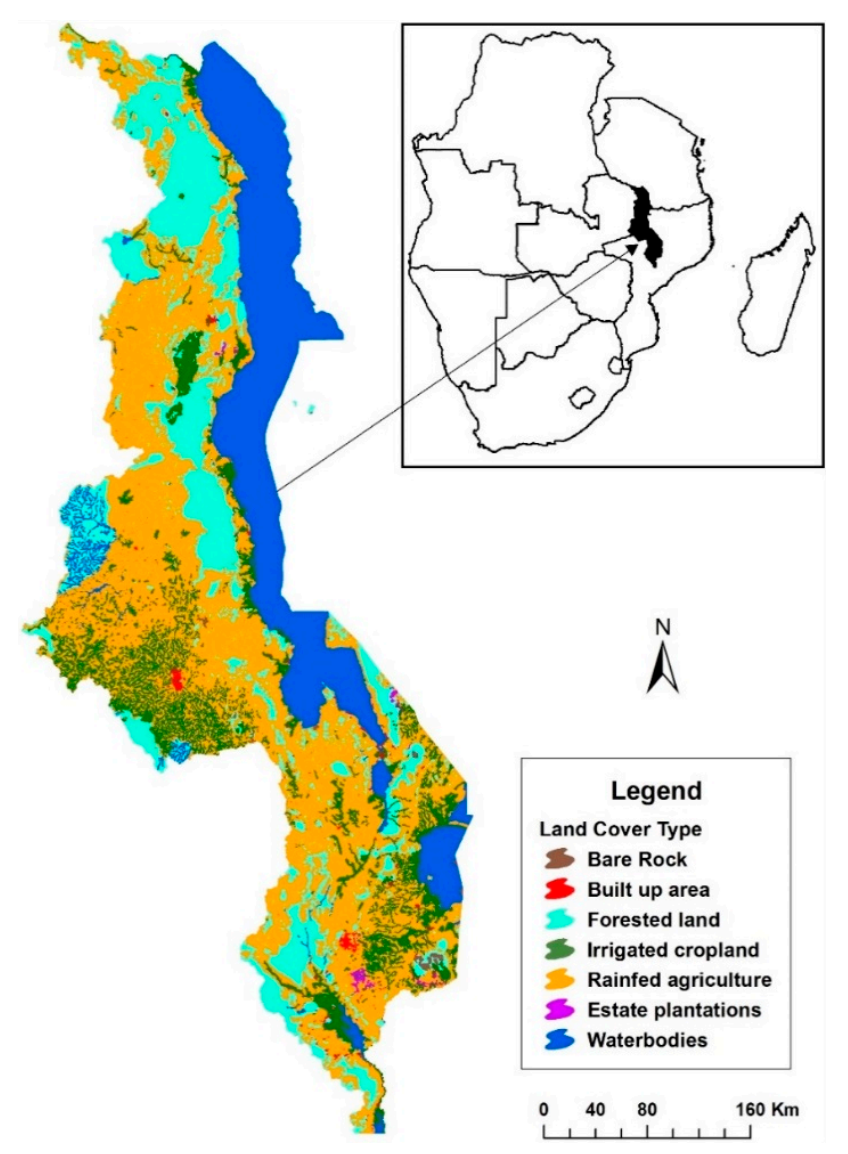

Figure 1. Landuse/cover and location map of Malawi. 
Although Malawi has vast water resources covering more than $20 \%$ of its land area, the recurrence of extreme weather events such as drought and flooding in recent years has resulted in increased food and water insecurity. The country is water stressed with less than $1700 \mathrm{~m}^{3}$ of freshwater per capita [19], and estimates for future water are less than $1000 \mathrm{~m}^{3}$ per capita by 2020, which places the country into the water scarce category [20]. Most of its surface water resources flow to neighbouring countries and groundwater resources remain largely untapped as agriculture is mostly rainfed. Only $1 \%$ of runoff water is captured for later use [21]. This provides an opportunity for implementing improved in-situ agricultural water management interventions like harvesting rainfall or field runoff that result in more soil moisture that could be used to bridge the intra-seasonal dry spells and increase crop yields.

\subsection{Definition of Crop Water Productivity}

Water productivity (WP) is a measure of the ability of agricultural systems to convert water into food [22]. Therefore, crop WP is a measure of output from a given agricultural system in relation to the water it consumes, and may be measured for a portion or the entire system [23]. It is expressed as:

$$
\mathrm{WP}=\frac{\text { Agriculture benefit }}{\text { Water consumed }}
$$

The agriculture benefit, the numerator in Equation (1), refers to the actual harvested yield expressed in units of mass like kilograms (kg), or it could refer to the monetary value (income) of that yield expressed in dollars. In this study, the total crop production of an agricultural system and the agriculture gross domestic product (Ag GDP) were used to calculate WP as a measure of mass and income, respectively. The denominator of the crop WP equation is described as water that is directly consumed by crops, which is often termed as actual or crop evapotranspiration $\left(\mathrm{ET}_{\mathrm{c}}\right)$. Water that is supplied to a crop field, but not consumed by the crops, should be excluded from calculating crop WP. For this reason, the measure of water supplied to a crop field cannot be effectively used to calculate crop WP. A way to measure water that is entirely consumed by crops is through crop evapotranspiration. Crop evapotranspiration is the consumption of water through evapotranspiration, which is incorporated into a product and cannot be readily reused $[7,24]$. Therefore, in this study the denominator of Equation (1) refers to crop evapotranspiration.

In this study, crop WP was calculated with respect to the amount of water directly consumed by crops in both rainfed and irrigated cropping systems through crop evapotranspiration $\left(\mathrm{ET}_{\mathrm{C}}\right)[25,26]$ and expressed in volumetric units $\left(\mathrm{m}^{3}\right)$ and depth $(\mathrm{mm})$. Crop WP is a measure of efficiency of the crop production process [27]. The main distinction when calculating WP is therefore to differentiate between water applied to an agricultural system and water consumed by it [23]. $\mathrm{ET}_{\mathrm{c}}$ therefore, is the amount of water that is entirely used by crops. This distinguishes WP from water use efficiency (WUE) and makes WP more conservative and comparable across temporal and spatial scales [25,28], making it a more useful parameter for assessing agricultural benefits derived from water use.

Moreover, WP is represented in units of $\mathrm{kg} / \mathrm{m}^{3}$, whereas crop productivity $(\mathrm{CP})$ is measured in $\mathrm{kg} / \mathrm{ha}$ and water use is estimated as $\mathrm{mm}$ of water applied or received as rainfall, converted to $\mathrm{m}^{3} / \mathrm{ha}$ $\left(1 \mathrm{~mm}=10 \mathrm{~m}^{3} / \mathrm{ha}\right)$. Alternatively, it may be represented as food $\left(\mathrm{kcal} / \mathrm{m}^{3}\right)$ or its monetary value $\left(\mathrm{US} \$ / \mathrm{m}^{3}\right)$.

\subsection{Estimating Crop Evapotranspiration (ET $T_{c}$ : Water Consumed}

At a field scale, $\mathrm{ET}_{\mathrm{c}}$ is an integral part of field management decision support tools that are used in irrigation planning and scheduling. The long-term average $\mathrm{ET}_{\mathrm{c}}$ was obtained from the yearly actual evapotranspiration $\left(\mathrm{ET}_{\mathrm{a}}\right.$ ) of the Moderate Resolution Imaging Spectroradiometer (MODIS's) Global Evapotranspiration Project (MOD16) [29] at $1 \mathrm{~km}$ resolution. The average annual $\mathrm{ET}_{\mathrm{a}}$ for every year between 2000 and 2013 from the MOD16 images was used to calculate the long-term annual average $\mathrm{ET}_{\mathrm{c}}$ for Malawi in ArcGIS. The long-term annual average $\mathrm{ET}_{\mathrm{c}}$ (Figure $2 \mathrm{~b}$ ) calculated for the reference period (2000-2013) was then used to calculate crop WP. The cultivated landuse under irrigated and 
rainfed agriculture systems (Figure 2a) was derived from the Land Cover Map of Malawi [30] shown in Figure 1. A constant annual average $\mathrm{ET}_{\mathrm{c}}$, expressed in $\mathrm{mm} / \mathrm{yr}$. for each of the agricultural systems was estimated by averaging the $\mathrm{ET}_{\mathrm{a}}$ of each system using the zonal statistics tool in ArcGIS, which was run on the cultivated land and $\mathrm{ET}_{\mathrm{C}}$ maps. The zonal statistics tool returns the average $\mathrm{ET}_{\mathrm{C}}$ of each zone (rainfed and irrigated), presented in Figure 2a, from each corresponding ET $_{c}$ pixel value (Figure $2 b$ ) of either rainfed or irrigated areas. The method excluded forested and other landuses that are not crops as indicated on Figure $2 \mathrm{a}$, which shows only irrigated and rainfed areas. The ET $\mathrm{a}$ for cultivated land represents the water used by crops and it is referred to as crop evapotranspiration $\left(\mathrm{ET}_{\mathrm{C}}\right)$. The calculated $\mathrm{ET}_{\mathrm{C}}$ accounted for all crop types, as it was calculated from the cropped area map and $\mathrm{ET}_{\mathrm{c}}$ map represented in grid format. Each grid of the $\mathrm{ET}_{\mathrm{c}}$ map has a unique value averaged over a long period of time. The developed $\mathrm{ET}_{\mathrm{c}}$ dataset $(\mathrm{mm})$ was converted to volumetric units $\left(\mathrm{km}^{3} \mathrm{or} \mathrm{m}^{3}\right)$ by multiplying the cultivated land area for each year and the $\mathrm{ET}_{\mathrm{c}}$ for the respective agricultural system. The $\mathrm{ET}_{\mathrm{c}}$ for each agricultural system, cultivated area (combined irrigated and rainfed), irrigated and rainfed landuses was calculated to evaluate their efficiency in WP.

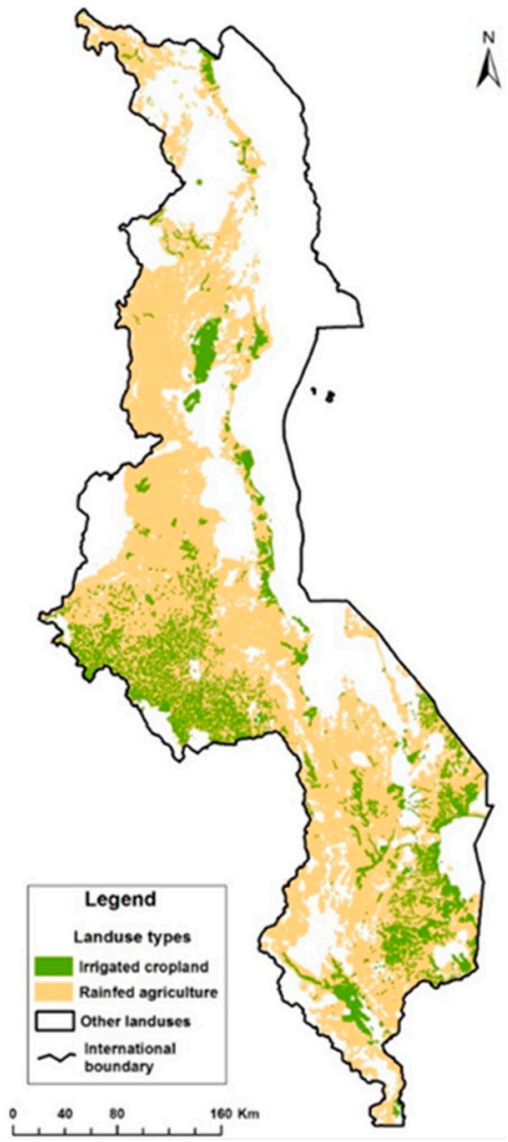

(a)

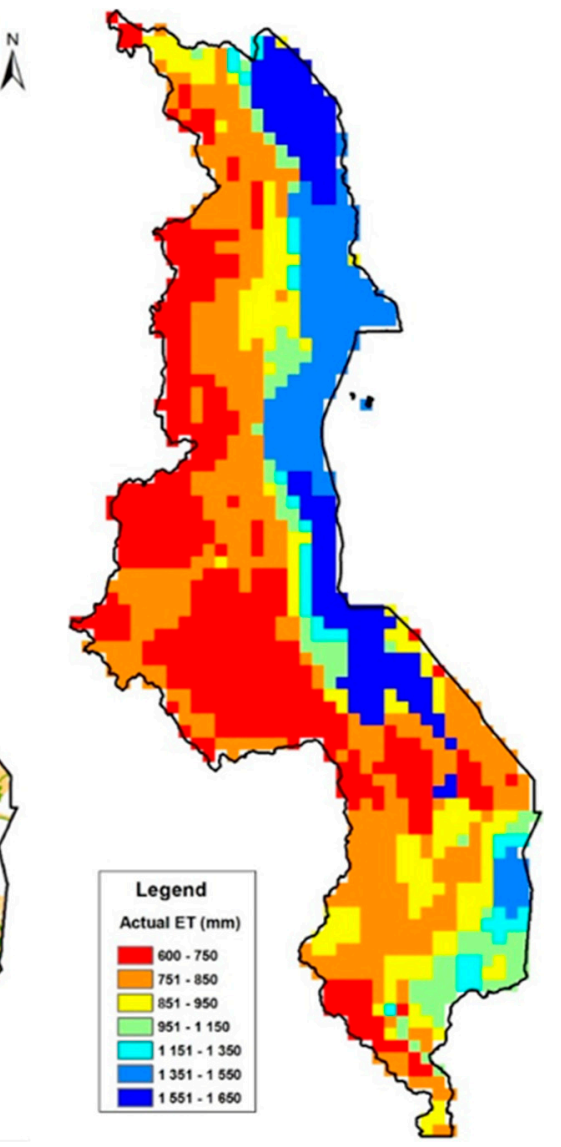

(b)

Figure 2. (a) Malawi's irrigated and rainfed agricultural land areas; and (b) long term actual evapotranspiration $\left(\mathrm{ET}_{\mathrm{a}}\right)$.

\subsection{Estimating the Agricultural Benefit: Production}

The outcome of an agricultural system can be expressed either as yield ( $\mathrm{kg}$ or $\mathrm{t}$ ), food equivalent (kcal.) or revenue (US\$). The physical WP was calculated using statistical data on crop production and crop area obtained from the Ministry of Agriculture, Irrigation and Water Development [31]. The economic WP was calculated using data on agriculture gross domestic product (Ag GDP) obtained from the World Bank's World Development Indicators [32]. The physical and economic data, together 
with the $\mathrm{ET}_{\mathrm{c}}$ for the individual agricultural system, were used to estimate WP in $\mathrm{kg} / \mathrm{m}^{3}$ or $\mathrm{kg} / \mathrm{ha} / \mathrm{mm}$ and US $\$ / \mathrm{m}^{3}$ or US $\$ / \mathrm{mm}$, respectively, using Equation (1).

\subsection{Crop Data Collection and Analysis}

The study assessed crop WP of all crops grown in Malawi, as a sum of total annual production between 2000 and 2013. The study separated the crop WP of irrigated and rainfed areas and compared the performance of the two agricultural systems. The $\mathrm{ET}_{\mathrm{c}}$ was therefore calculated as an average of all crops and not for a single crop in particular. A long-term average $\mathrm{ET}_{\mathrm{c}}$ for the years was evaluated, and not for a particular year. The data on annual crop production for both rainfed and irrigated areas were obtained from the Ministry of Agriculture, Irrigation and Water Development of Malawi through a questionnaire. The questionnaire asked information on total area cultivated and total crop production from 2000 to 2013. Although maize is the major cereal grown and consumed in the country, other crops grown include wheat, groundnuts, sorghum, millet, pulses, rice, root crops, vegetables, fruits, and tobacco, among others.

\section{Results}

\subsection{Crop Evapotranspiration $\left(E T_{\mathcal{c}}\right)$ of Cropping Systems}

The cultivated land (map a) and $\mathrm{ET}_{\mathrm{a}}$ (map b) of Malawi are presented in Figure 2. The two maps were used to estimate $\mathrm{ET}_{\mathrm{c}}$. The white sections in the agricultural land area map (map a), labelled as other landuses, are excluded from calculated $\mathrm{ET}_{\mathrm{c}}$ as they were occupied by other landuses which were not crops. On the $\mathrm{ET}_{\mathrm{a}}$ (map b), the areas with evapotranspiration values higher than $1100 \mathrm{~mm}$ were areas generally occupied by water bodies and were also excluded from calculating $\mathrm{ET}_{\mathrm{c}}$.

The average annual $\mathrm{ET}_{\mathrm{C}}$ calculated for each agricultural system of rainfed, irrigated and combined cultivated land were 834.7, 902.5 and $842.6 \mathrm{~mm}$, respectively. These average $\mathrm{ET}_{\mathrm{c}}$ values represent water that was consumed by crops in each of the agricultural systems. However, the total $\mathrm{ET}_{\mathrm{C}}$ changed annually with the changing cropped area when converted to volumetric units (Tables 1-3).

The $\mathrm{ET}_{\mathrm{c}}$ was evidently higher in irrigated areas relative to rainfed areas as crops were not stressed in irrigated systems as water was applied in timely increments before the crop was stressed compared to rainfed where crops are stressed during dry periods. Although the $\mathrm{ET}_{\mathrm{c}}$ for both rainfed and irrigated agricultural systems increased with the increasing cropped area annually, crop water consumption was evidently better managed in irrigated than rainfed agriculture. This was demonstrated in Table 1 where both water and crop productivity were always higher in the irrigated than rainfed system. 
Table 1. Comparison of water productivity between rainfed and irrigated systems in Malawi.

\begin{tabular}{|c|c|c|c|c|c|c|c|c|c|c|}
\hline \multirow[b]{2}{*}{ Year } & \multicolumn{5}{|c|}{ Irrigated Cultivation } & \multicolumn{5}{|c|}{ Rainfed Cultivation } \\
\hline & $\begin{array}{c}\text { Area } \\
\left(\mathbf{k m}^{2}\right)\end{array}$ & $\begin{array}{c}\text { Crop Production } \\
\text { (Billion kg) }\end{array}$ & $\begin{array}{c}\mathrm{CP} \\
\left(1000 \mathrm{~kg} / \mathrm{km}^{2}\right) \\
\end{array}$ & $\mathrm{ET}_{\mathrm{c}}\left(\right.$ Billion $\left.\mathrm{m}^{3}\right)$ & $\mathrm{WP}\left(\mathrm{kg} / \mathrm{m}^{3}\right)$ & $\begin{array}{c}\text { Area } \\
\left(\mathrm{km}^{2}\right)\end{array}$ & $\begin{array}{c}\text { Crop Production } \\
\text { (Billion kg) }\end{array}$ & $\begin{array}{c}\mathrm{CP} \\
\left(1000 \mathrm{~kg} / \mathrm{km}^{2}\right) \\
\end{array}$ & $\mathrm{ET}_{\mathrm{c}}\left(\right.$ Billion $\left.\mathrm{m}^{3}\right)$ & $W P\left(\mathrm{~kg} / \mathrm{m}^{3}\right)$ \\
\hline 2000 & 907.32 & 0.31 & 341.7 & 0.82 & 0.378 & $29,154.74$ & 6.94 & 238.0 & 24.34 & 0.285 \\
\hline 2001 & 1271.15 & 0.42 & 330.4 & 1.15 & 0.370 & $47,767.53$ & 7.40 & 154.9 & 39.87 & 0.186 \\
\hline 2002 & 1574.44 & 0.34 & 215.9 & 1.42 & 0.240 & $32,884.44$ & 4.37 & 132.9 & 27.45 & 0.159 \\
\hline 2003 & 1933.86 & 0.51 & 263.7 & 1.75 & 0.293 & $33,451.95$ & 5.57 & 166.5 & 27.92 & 0.199 \\
\hline 2004 & 2178.29 & 0.72 & 330.5 & 1.97 & 0.367 & $33,451.95$ & 3.63 & 108.5 & 27.92 & 0.130 \\
\hline 2005 & 1706.03 & 0.40 & 234.5 & 1.54 & 0.261 & $28,078.93$ & 3.74 & 133.2 & 23.44 & 0.160 \\
\hline 2006 & 2185.12 & 0.71 & 324.9 & 1.97 & 0.362 & $29,226.05$ & 6.89 & 235.7 & 24.40 & 0.282 \\
\hline 2007 & 2491.56 & 0.91 & 365.2 & 2.25 & 0.403 & $31,135.11$ & 8.61 & 276.5 & 25.99 & 0.331 \\
\hline 2008 & 2777.50 & 1.22 & 439.2 & 2.51 & 0.485 & $17,371.33$ & 5.95 & 342.5 & 14.50 & 0.410 \\
\hline 2009 & 2896.57 & 1.42 & 490.2 & 2.61 & 0.543 & $32,942.30$ & 9.86 & 299.3 & 27.50 & 0.359 \\
\hline 2010 & 2902.34 & 1.41 & 485.8 & 2.62 & 0.537 & $33,670.79$ & 10.08 & 299.4 & 28.11 & 0.359 \\
\hline 2011 & 3072.32 & 1.54 & 501.2 & 2.77 & 0.554 & $33,065.33$ & 10.73 & 324.5 & 27.60 & 0.389 \\
\hline 2012 & 3288.12 & 1.72 & 523.1 & 2.97 & 0.580 & $37,062.50$ & 11.25 & 303.5 & 30.94 & 0.364 \\
\hline 2013 & 3405.83 & 1.85 & 543.2 & 3.07 & 0.603 & $34,807.56$ & 11.58 & 332.7 & 29.05 & 0.398 \\
\hline
\end{tabular}

Notes: $\mathrm{CP}-\mathrm{Crop}$ productivity; $\mathrm{ET}_{\mathrm{c}}-$ Crop evapotranspiration; WP—Water productivity 
Table 2. Water productivity calculated from total crop yield in Malawi.

\begin{tabular}{|c|c|c|c|c|}
\hline Year & Cultivated Area $\left(\mathrm{km}^{2}\right)$ & Crop Production (Billion kg) & $\mathrm{ET}_{\mathrm{c}}\left(\right.$ Billion $\left.\mathrm{m}^{3}\right)$ & $\mathrm{WP}\left(\mathrm{kg} / \mathrm{m}^{3}\right)$ \\
\hline 2000 & $30,062.06$ & 7.25 & 25.33 & 0.286 \\
\hline 2001 & $49,038.68$ & 7.83 & 41.32 & 0.189 \\
\hline 2002 & $34,458.88$ & 4.71 & 29.04 & 0.162 \\
\hline 2003 & $35,385.81$ & 6.08 & 29.82 & 0.204 \\
\hline 2004 & $35,630.24$ & 4.35 & 30.02 & 0.145 \\
\hline 2005 & $29,784.96$ & 4.14 & 25.10 & 0.165 \\
\hline 2006 & $31,411.17$ & 7.60 & 26.47 & 0.287 \\
\hline 2007 & $33,626.67$ & 9.52 & 28.33 & 0.336 \\
\hline 2008 & $20,148.83$ & 7.17 & 16.98 & 0.422 \\
\hline 2009 & $35,838.87$ & 11.28 & 30.20 & 0.373 \\
\hline 2010 & $36,573.13$ & 11.49 & 30.82 & 0.373 \\
\hline 2011 & $36,137.65$ & 12.26 & 30.45 & 0.403 \\
\hline 2012 & $40,350.62$ & 12.97 & 34.00 & 0.381 \\
\hline 2013 & $38,213.39$ & 13.43 & 32.20 & 0.417 \\
\hline
\end{tabular}

Notes: $\mathrm{ET}_{\mathrm{c}}$-Crop evapotranspiration; WP-Water productivity.

Table 3. Water productivity calculated from agricultural gross domestic product (Ag GDP) in Malawi.

\begin{tabular}{ccccc}
\hline Year & Cultivated Area $\left.\mathbf{( k m}^{\mathbf{2}}\right)$ & Agric. GDP (Billion US\$) & ET $_{\mathbf{c}}$ (Billion $\left.\mathbf{~ m}^{\mathbf{3}}\right)$ & $\mathbf{W P}\left(\mathbf{U S} \mathbf{\$} \mathbf{m}^{\mathbf{3}}\right)$ \\
\hline 2000 & $30,062.06$ & 0.7 & 25.33 & 0.027 \\
2001 & $49,038.68$ & 0.7 & 41.32 & 0.016 \\
2002 & $34,458.88$ & 1.0 & 29.04 & 0.034 \\
2003 & $35,385.81$ & 0.9 & 29.82 & 0.029 \\
2004 & $35,630.24$ & 0.9 & 30.02 & 0.031 \\
2005 & $29,784.96$ & 0.9 & 25.10 & 0.036 \\
2006 & $31,411.17$ & 1.0 & 26.47 & 0.037 \\
2007 & $33,626.67$ & 1.2 & 28.33 & 0.041 \\
2008 & $20,148.83$ & 1.3 & 16.98 & 0.075 \\
2009 & $35,838.87$ & 1.6 & 30.20 & 0.052 \\
2010 & $36,573.13$ & 1.6 & 30.82 & 0.052 \\
2011 & $36,137.65$ & 1.8 & 30.45 & 0.057 \\
2012 & $40,350.62$ & 1.3 & 34.00 & 0.038 \\
2013 & $38,213.39$ & 1.3 & 32.20 & 0.040 \\
2014 & $48,203.24$ & 1.4 & 40.62 & 0.035 \\
\hline
\end{tabular}

Notes: Agric. GDP—Agriculture GDP; $\mathrm{ET}_{\mathfrak{c}}$-Crop evapotranspiration; WP—Water productivity.

\subsection{Comparison of the Water Productivity in Rainfed and Irrigated Systems}

The differences in the physical WP of irrigated and rainfed systems for every year between 2000 and 2013 are shown in Table 1. As expected, the rainfed WP was lower than irrigated WP, due to better control of water supply to the field, provided that water is available from the source or storage. Physical WP in the irrigated system increased by 50\% between 2000 and 2013, whereas in the rainfed system, it increased by only $33 \%$ during the same period. This difference demonstrates that more yield is being produced in irrigated agriculture per each unit of water consumed than in rainfed agriculture. This was as a result of better management practices, including better control of crop water supply in irrigated agriculture. This was supported by the higher increasing rate of crop productivity $(C P)$ in irrigated agriculture as compared to that of rainfed agriculture (Table 1). Crop productivity increased by $59 \%$ in irrigated agriculture, but in rainfed agriculture, it increased by only $40 \%$ during the same period between 2000 and 2013. However, the results indicated that more water was still being directed towards the agriculture sector as the overall $\mathrm{ET}_{\mathrm{c}}$ increased by $27 \%$ between 2000 and 2013.

Crop WP calculated from the total crop yield, that is the total crop production from both irrigated and rainfed agricultural systems is presented in Table 2. Although the combined WP increased annually, it was far below the irrigated agriculture WP alone as illustrated in Figure 3. The total 
combined crop WP fluctuated over the years due to the recurrence of floods and drought in the country. These climate calamities affected mostly the rainfed system because of non-existent agricultural water management practices. The combined crop WP increased by 33\% between 2000 and 2013, far below the increase of $59 \%$ observed for irrigated agriculture during the same period.

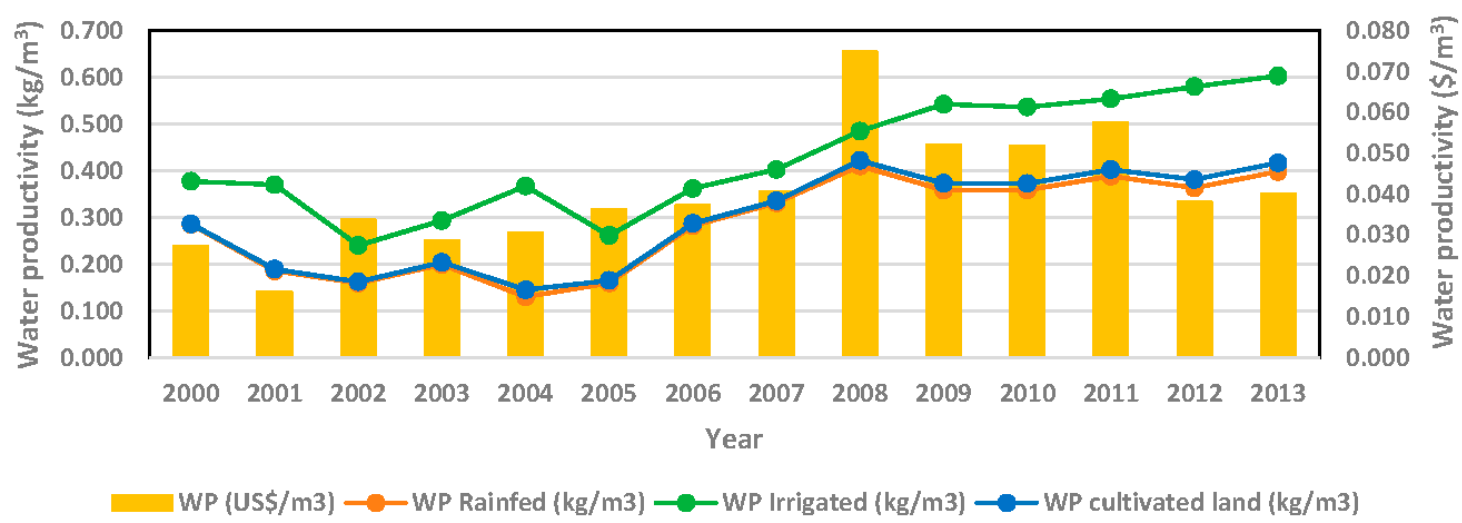

Figure 3. Comparison in the trends of physical and economic water productivity over time.

The combined WP trend-line from cultivated land was almost the same as the rainfed agriculture WP trend-line in shape and values (Figure 3), indicating that rainfed WP contributed significantly in reducing the combined WP. The irrigated WP trend-line was well above both the rainfed and combined trend-lines. The gap between the irrigated and rainfed WP trend-lines continued to widen over time as irrigated WP continued to improve, further demonstrating better water management practices in irrigated agriculture.

The revenue (income) that was being generated annually per every unit of water used expressed in US\$ is presented in Table 3. The economic WP increased by 30\% between 2000 and 2013. The revenue (Table 3) per unit of water consumed increased variably over the years because of various climatic events that affected the country's rainfed system. Nevertheless, in later years, more revenue was being realised with less water than in previous years. The performance of the economic WP over the years in relation to physical WP is indicated in Figure 3. The economic WP was highly dependent and correlated with the performance of the physical WP. If physical WP is high, more crops are being produced per every unit of water consumed, and this means that more economic value will also be realised per every unit of water consumed.

\section{Discussion}

Despite Malawi's vast water resources, water scarcity is commonplace due to current water management practices, changing climate, and increased urbanisation. Major factors for improved crop WP in Malawi include: (a) the use of improved agronomic practices; (b) investment towards smallholder farmers; and (c) the expansion of the smallholder irrigated area. For example, the Malawi Agricultural Input Subsidy Programme (MAISP), now called the Farm Input Subsidy Programme (FISP), allowed smallholder farmers to purchase fertilisers, improved varieties and other chemicals at subsidised prices, thereby enabling them to produce more yield per unit area [19,33]. Improved agronomic practices promoted high crop WP, indicating that yields will only improve if other stresses (e.g., nutrient deficiencies, weeds and diseases) are also alleviated or removed [14,34]. Government policies and investment in Malawi are promoting an expansion in the acreage of smallholder irrigation schemes [19]. Malawi has recently experienced a revitalisation of old and dysfunctional irrigation schemes as well as the development of new ones. In 2005, smallholder irrigation schemes had a total area of 15,988 ha, but increased to 42,986 ha in 2011, representing an increase of $169 \%$ [19,21,31]. Consistent with the increase in land under smallholder irrigation schemes, total crop production from irrigated areas increased from 443,715 tons to $1,693,920$ tons (an increase of $282 \%$ ) over the same period [19,31]. 
An exceptional year was 2008, which recorded the highest physical and economic WP of $0.422 \mathrm{~kg} / \mathrm{m}^{3}(0.0422 \mathrm{~kg} / \mathrm{ha} / \mathrm{mm})$ and $0.075 \mathrm{US} \$ / \mathrm{m}^{3}(0.0075 \mathrm{US} \$ / \mathrm{ha} / \mathrm{mm})$ as shown in Tables 2 and 3 , respectively. The high WP in 2008 was attributed to high crop yields achieved that year in relation to the proportion of the cropped area, which was relatively smaller than the other years (i.e., increased crop productivity). The cropped area decreased in 2008 as some of the cultivated areas were affected by flooding that year. Nevertheless, crop production from areas not affected by flooding performed quite well as the country managed to export some food crops such as maize [19,31]. Exportation resulted in high revenues in 2008 as there was an increase in world crop prices [35]. Crop and water productivity increased as agronomic practices were improved when the government provided subsidised fertilizers and other chemicals to smallholder farmers during that agricultural season.

Timely intervention in the smallholder farming sector is resulting in improved crop WP and increased crop production, which has boosted incomes and food security. For example, total maize production alone increased from 1.2 million metric tons during the 2004/05 season to 3.6 million metric tons in 2012/13 season (an increase of 200\%) [19,21]. The benefits of the interventions have transformed Malawi from a net importer to a net exporter of maize since 2006 to date.

The rainfed WP values for Malawi, calculated for this study, were between $0.29 \mathrm{~kg} / \mathrm{m}^{3}$ and $0.4 \mathrm{~kg} / \mathrm{m}^{3}$, which are slightly lower compared to other global studies that found WP values ranging from $0.35 \mathrm{~kg} / \mathrm{m}^{3}$ to $1.1 \mathrm{~kg} / \mathrm{m}^{3}$ [14,36], suggesting there is still room for WP improvement in Malawi. The use of satellite data to calculate crop evapotranspiration not only enabled calculating WP of a data scarce country, but it also improved the results of previous studies.

\section{Conclusions}

The need to mitigate the challenges of limited land, water scarcity and food insecurity in Malawi requires the sustainable production of more food with relatively less water and land. As an agro-based economy, the agriculture sector will always withdraw the bulk of freshwater resources. In Malawi, the option of increasing rainfed area is not feasible as land is limited due to its small extent of arable land. Thus, technical and policy support in introducing crop varieties suitable for a changing climate, promoting rain water harvesting and conservation as well as improving agronomic practices are the most viable solutions for improving physical and economic water productivity of rainfed agricultural systems. Intensifying irrigation and improving agronomic practices in the rainfed systems will improve WP and will provide more water for other multiple users downstream. This will allow for more water to be allocated to other economic sectors such as energy generation and environmental flows to support other ecosystems. Improving WP through expanding or intensifying irrigation (with an average WP of $0.43 \mathrm{~kg} / \mathrm{m}^{3}$ ) is probably the best option as most of the existing agriculture land is rainfed, (with an average WP of $0.29 \mathrm{~kg} / \mathrm{m}^{3}$ ) given the limited land in Malawi. Although irrigation expansion may result in more water consumed by the agriculture sector, which will deprive other sectors of the scarce resource, it is inevitable since the economy is agro-based, and any deprivation of water in the agriculture sector may affect economic performance. Promoting rain water harvesting techniques could also provide an additional source of water for providing supplementary irrigation during dry spells. This, combined with better irrigation scheduling techniques, such as deficit irrigation, could translate to improvements in water use efficiency. This would allow for an expansion in irrigated agriculture without adding significantly to the current withdrawals from agriculture. Thus, irrigation agriculture should be supported by improvements in water use efficiency.

Acknowledgments: The authors would like to thank the United States Agency for International Development (USAID) for providing financial assistance for the Agricultural Water (Ag Water) Outlook and Trends research project under the Feed the Future $(\mathrm{FtF})$ programme.

Author Contributions: Luxon Nhamo designed the study, wrote the manuscript and led the data acquisition and analysis. Tafadzwanashe Mabhaudhi helped with data acquisition, result interpretation and writing of the manuscript. Manuel Magombeyi contributed to data interpretation and the writing of the manuscript.

Conflicts of Interest: The authors declare no conflict of interest. 


\section{References}

1. Postel, S.L. Securing water for people, crops, and ecosystems: New mindset and new priorities. Nat. Resour. Forum 2003, 27, 89-98. [CrossRef]

2. Rosegrant, M.W.; Ringler, C.; Zhu, T. Water for agriculture: Maintaining food security under growing scarcity. Annu. Rev. Environ. Resour. 2009, 34, 205-222. [CrossRef]

3. Brauman, K.A.; Siebert, S.; Foley, J.A. Improvements in crop water productivity increase water sustainability and food security-a global analysis. Environ. Res. Lett. 2013, 8, 024030. [CrossRef]

4. Passioura, J. Increasing crop productivity when water is scarce-From breeding to field management. Agric. Water Manag. 2006, 80, 176-196. [CrossRef]

5. Molden, D.; Oweis, T.Y.; Pasquale, S.; Kijne, J.W.; Hanjra, M.A.; Bindraban, P.; Bouman, B.A.; Cook, S.; Erenstein, O.; Farahani, H.; et al. Pathways for increasing agricultural water productivity. In Water for Food, Water for Life: A Comprehensive Assessment of Water Management in Agriculture; Molden, D., Ed.; Earthscan Publications: London, UK; International Water Management Institute (IWMI): Colombo, Sri Lanka, 2007; pp. 279-310.

6. Sharma, B.; Molden, D.; Cook, S. Water use efficiency in agriculture: Measurement, current situation and trends. In Managing Water and Fertilizer for Sustainable Agricultural Intensification; Drechsel, P., Heffer, P., Magen, H., Mikkelsen, R., Wichelns, D., Eds.; International Water Management Institute (IWMI): Colombo, Sri Lanka, 2015; pp. 39-64.

7. Molden, D.; Oweis, T.; Steduto, P.; Bindraban, P.; Hanjra, M.A.; Kijne, J. Improving agricultural water productivity: Between optimism and caution. Agric. Water Manag. 2010, 97, 528-535. [CrossRef]

8. Hamdy, A.; Ragab, R.; Scarascia-Mugnozza, E. Coping with water scarcity: Water saving and increasing water productivity. Irrig. Drain. 2003, 52, 3-20. [CrossRef]

9. Ali, M.; Talukder, M. Increasing water productivity in crop production-A synthesis. Agric. Water Manag. 2008, 95, 1201-1213. [CrossRef]

10. Renault, D.; Wallender, W. Nutritional water productivity and diets. Agric. Water Manag. 2000, 45, $275-296$. [CrossRef]

11. De Fraiture, C.; Molden, D.; Wichelns, D. Investing in water for food, ecosystems, and livelihoods: An overview of the comprehensive assessment of water management in agriculture. Agric. Water Manag. 2010, 97, 495-501. [CrossRef]

12. Amarasinghe, U.A.; Smakhtin, V. Water productivity and water footprint: Misguided concepts or useful tools in water management and policy? Water Int. 2014, 39, 1000-1017. [CrossRef]

13. Chirwa, E.W.; Kumwenda, I.; Jumbe, C.; Chilonda, P.; Minde, I. Agricultural Growth and Poverty Reduction in Malawi: Past Performance and Recent Trends; International Water Management Institute (IWMI): Colombo, Sri Lanka, 2008.

14. Descheemaeker, K.; Bunting, S.W.; Bindraban, P.; Muthuri, C.; Molden, D.; Beveridge, M.; van Brakel, M.; Herrero, M.; Clement, F.; Boelee, E.; et al. Increasing water productivity in agriculture. In Managing Water and Agroecosystems for Food Security; Boelee, E., Ed.; CAB International: Wallingford, UK, 2013; Volume 10, pp. 104-123.

15. Kumar, M.D.; Singh, O.; Samad, M.; Purohit, C.; Didyala, M.S. Water Productivity of Irrigated Agriculture in India: Potential Areas for Improvement. In Proceedings of the 7th IWMI-Tata Annual Partners' Meet of IWMI-Tata Water Policy Research Program, New Delhi, India, 2-4 April 2008.

16. Fanadzo, M.; Chiduza, C.; Mnkeni, P.; Van der Stoep, I.; Stevens, J. Crop production management practices as a cause for low water productivity at zanyokwe irrigation scheme. Water SA 2010, 36, 27-36. [CrossRef]

17. Molua, E.L.; Lambi, C.M. Assessing the Impact of Climate on Crop Water Use and Crop Water Productivity: The CROPWAT Analysis of Three Districts in Cameroon; University of Pretoria: Pretoria, South Africa, 2006; p. 44.

18. National Statistical Office (NSO). National Statistical System Strategic Plan 2013-2017; NSO: Zomba, Malawi, 2013.

19. Nhamo, L.; Matchaya, G.; Nhemachena, C.; van Koppen, B. The impact of investment in smallholder irrigation schemes on irrigation expansion and crop productivity in Malawi. Afr. J. Agric. Resour. Econ. 2016, 11, 141-153.

20. Rijsberman, F.R. Water scarcity: Fact or fiction? Agric. Water Manag. 2006, 80, 5-22. [CrossRef] 
21. Kumwenda, I.; van Koppen, B.; Matete, M.; Nhamo, L. Trends and Outlook: Agricultural Water Management in Southern Africa, Country Report Malawi; International Water Mnagement Institute (IWMI): Colombo, Sri Lanka, 2015.

22. Kijne, J.W.; Barker, R.; Molden, D.J. Water Productivity in Agriculture: Limits and Opportunities for Improvement; CABI International: Wallingford, UK, 2003.

23. Cook, S.; Gichuki, F.; Turral, H. Water Productivity: Estimation at Plot, Farm and Basin Scale; CGIAR Challenge Program on Water and Food: Colombo, Sri Lanka, 2006.

24. Seckler, D. The New Era of Water Resources Management: From "Dry" to "Wet" Water Savings; Research Report 1; International Water Management Institute (IWMI): Colombo, Sri Lanka, 1996.

25. Zwart, S.J.; Bastiaanssen, W.G. Review of measured crop water productivity values for irrigated wheat, rice, cotton and maize. Agric. Water Manag. 2004, 69, 115-133. [CrossRef]

26. Perry, C.; Steduto, P.; Allen, R.G.; Burt, C.M. Increasing productivity in irrigated agriculture: Agronomic constraints and hydrological realities. Agric. Water Manag. 2009, 96, 1517-1524. [CrossRef]

27. Van Halsema, G.E.; Vincent, L. Efficiency and productivity terms for water management: A matter of contextual relativism versus general absolutism. Agric. Water Manag. 2012, 108, 9-15. [CrossRef]

28. Steduto, P.; Hsiao, T.C.; Fereres, E. On the conservative behavior of biomass water productivity. Irrig. Sci. 2007, 25, 189-207. [CrossRef]

29. Mu, Q.; Zhao, M.; Running, S.W. Improvements to a modis global terrestrial evapotranspiration algorithm. Remote Sens. Environ. 2011, 115, 1781-1800. [CrossRef]

30. Food and Agriculture Organisation of the United Nations (FAO). Atlas of Malawi Land Cover and Land Cover Change 1990-2010; FAO: Rome, Italy, 2013.

31. Ministry of Agriculture, Irrigation and Water Development (MoAIWD). Malawi Sector Performance Report 2014; MoAIWD: Lilongwe, Malawi, 2014; p. 106.

32. World-Bank. World Development Indicators 2015; World Bank: Washington, DC, USA, 2015.

33. Dorward, A.; Chirwa, E. The Malawi agricultural input subsidy programme: 2005/06 to 2008/09. Int. J. Agric. Sustain. 2011, 9, 232-247. [CrossRef]

34. Bouman, B. A conceptual framework for the improvement of crop water productivity at different spatial scales. Agric. Syst. 2007, 93, 43-60. [CrossRef]

35. Food and Agricultural Organization of the United Nations (FAO). The State of Food Insecurity in the World 2012, Economic Growth is Necessary but not Sufficient to Accelerate Reduction of Hunger and Malnutrition; FAO: Rome, Italy, 2012.

36. Rockström, J.; Barron, J. Water productivity in rainfed systems: Overview of challenges and analysis of opportunities in water scarcity prone savannahs. Irrig. Sci. 2007, 25, 299-311. [CrossRef]

(C) 2016 by the authors; licensee MDPI, Basel, Switzerland. This article is an open access article distributed under the terms and conditions of the Creative Commons Attribution (CC-BY) license (http:/ / creativecommons.org/licenses/by/4.0/). 